game, waterfowl and furbearer investigation. Unpublished Report.

"GERRARD, J. M., and D. W. A. WHITFIELD. 1967. Bald Eagle banding in northern Saskatchewan. Blue Jay 25:177-183.

${ }^{4}$ GER RARD, J. M. 1973. Eagle census experiences in Canada. In notes on a Bald Eagle nest survey workshop. Ed. C. R. Madsen, U. S. Dept. Interior.

'HENSEL, R. J., and W. A. TROYER. 1964. Nesting studies of the Bald Eagle in Alaska. Canada 66:282-286.

${ }^{6}$ HERRICK, F. H. 1934. The American eagle. New York. D. Appelton-Century Co., New York, N.Y., 267 p.

JJUENEMANN, B. G. 1973. Habitat evaluation of selected Bald Eagle nest sites on the Chippewa National Forest. M.Sc. Thesis. Univ. Minnesota, Minneapolis.

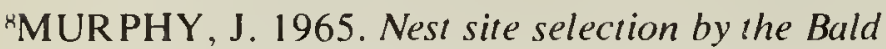
Eagle in Yellowstone National Park. Utah Academy of Sciences, Arts and Letters (Provo) Proc. Vol. 42, Part 2:261-264.
"POULIN, E. M. 1968. Bald Eagle nest ecology. Federal Aid in Fish and Wildlife Restoration. Alaska W-13-R-3, Work Plan B, Job 9. Small game and furbearer investigations. Unpublished report.

"RETFALVI, L. I. 1965. Breeding behavior and feeding habits of the Bald Eagle (Haliaetus leucocephalus L.) on San Juan Island, Washington. M. Forestry Thesis. Univ. British Columbia, Vancouver. 193 p.

"RICHARDS, J. H., and K. I. FUNG (Editors) 1969. Atlas of Saskatchewan. Univ. Saskat chewan, Saskatoon. 236 p.

${ }^{12}$ ROWE, J. S. 1972. Forest regions of Canada Canadian Forestry Service, Ottawa. 172 p.

1:3HITFIELD, D. W. A., J. M. GERRARD, W J. MAHER, and D. W. DAVIS. 1974. Balk Eagle nesting habitat, density, and reproduction in Central Saskatchewan and Manitoba. Can. Field Nat. 88:399-407.

\title{
FIRST RECORDS OF THE ORCHARD ORIOLE IN SASKATCHEWAN
}

\author{
by E. MANLEY CALLIN*
}

On three dates from June 19 to June 28, 1974, I stopped briefly at the P.F.R.A. dam over the river at the northern edge of the town of Fort Qu'Appelle and in an adjacent, heavily wooded area I heard a lively warble similar to the Purple Finch. The bird could not be seen from the perimeter of the woods and it was singing from a residential area. On June 29 I asked the residents, Constable John Lloyd and his wife, for permission to enter

*Fort Qu'Appelle, Saskatchewan the area for the purpose of observin and recording. They were mos obliging and during the next hour taped about 35 songs but the bird w? extremely shy and not once could I ge a glimpse of it.

On June 30 Jack Lowe of For Qu'Appelle and on July 1 Fran Brazier of Regina assisted in th search for identity of the elusive bir which sang regularly but remaine hidden in the upper portion of a ver high spruce tree. During these tw days more songs and calls were reco 
ed but, more importantly, a few creened views were obtained and it as determined that our bird was an rrchard Oriole, a new species for the rovince. However, it was not in the ch, mature plumage but in the much hore modest attire of a first year male almost all yellowish colour plus a lack throat).

The Saskatchewan Museum of atural History at Regina was notified id on July 3 two employees, Robert ong and Dwayne Harty, visited the rea to confirm the find. More songs ere recorded, the bird was becoming ss shy and great patience enabled ong to take a few satisfactory picres. On this occasion we had a few, cry brief, views of a bird which we onsidered to be a female Orchard riole.

\section{From July 4 to 12 , I made daily} sits, usually just stopping for a few inutes as I drove by, and the male as still singing regularly. On July 13 , spent about an hour in the area, eard young birds clamoring for food id watched both parents, mostly the male, carrying food to a particular anch. The nest could not be seen, as was well hidden, and we did not atmpt to climb the tree. However, the st was about 25 feet above ground in blue spruce about 35 feet in height id it was located half-way out on a anch about 6 feet long. Also, the sting tree was so close to the male's vourite singing tree that the branches erlapped considerably.

Feeding of the young was again obrved on July 14,15 and 16 but the ung left the nest after this time. On lly 17 there was no activity in the sting area but the usual sharp, alarm tes of the male were heard in a grove maples about 25 yards to the east. ere I found the male flying around citedly and after a brief search scovered one young moving from anch to branch in a fairly competent anner. The female was not seen and only one young could be found. No birds were heard or seen on July 18 but, upon returning on July 22 , I again found the male and one young. Apparently the family left the area on July 22 as no birds were heard or seen on later visits.

Summary and Queries: The male sang regularly from June 19 until the young left the nest on July 17. Most of the feeding was done by the female. As time went on, both birds were progressively less shy. Did they become accustomed to our presence or did the rearing of a family create a greater urgency than the fear of humans? Does the Orchard Oriole have a reputation as a shy bird? Orchard Orioles are so rare in Saskatchewan that one is inclined to speculate that this pair must have arrived together. This record involves a first year male and so also does Binnie's record of 1972 (see below). Are young males more aggressive and, therefore, more likely to advance into new territory? Do the Manitoba records of 1974 provide a possible answer? It may be worthy of comment that Saskatchewan is the only province where all three species or well-marked sub-species of Orioles to be found in Canada have now been recorded.

Although the above is the first confirmed record and nesting for the province, I have been advised of a very reliable and interesting record of the Orchard Oriole at Regina in 1972. By telephone and correspondence, Al Binnie informs me that in June of 1972 a first year male spent almost 2 weeks in the mixed woods at the Correctional Institute at Regina. Al and his wife, Betty, had listened to an unfamiliar song for nearly a week, finally observed and identified the singer on June 19 and it was last seen on June 25 .

Al stated that almost always the bird remained hidden and was very difficult to observe. He alerted some Regina birders and several had come to see the bird but none of them were able to stay long enough to get a view of it. This is understandable when I recall the extreme difficulty that Jack Lowe and I had for $4-1 / 2$ hours at Fort Qu'Appelle on June 30, 1974.

I would like to thank all those persons mentioned in this article as they have made a valued contribution and, in some instances, expended hours of time and patience. I would also like to thank Mrs. Lily Cochrane of Fort Qu'Appelle who contributed her professional skill in the typing of this report 